\title{
Correction to: Addressing multicultural societies: lessons from religious education curriculum policy in Indonesia and England
}

\author{
Nurwanto $^{1}$ (D) Carole M. Cusack $^{2}$
}

Published online: 17 November 2017

(C) Australian Catholic University 2017

\section{Correction to: J Relig Educ 64:157-178 https://doi.org.10.1007/s40839-017-0040-x}

Unfortunately, a mistake was discovered in the reference for Alistair Ross. The article refers to Alistair, R. whereas it should be Ross, A.

Please find here the correct reference:

Ross, A. (2000). Curriculum construction and critique. New York: Falmer Press.

The original article can be found online at https://doi.org.10.1007/s40839-017-0040-x.

$\triangle$ Nurwanto

nurwanto@umy.ac.id

Carole M. Cusack

carole.cusack@sydney.edu.au

1 Universitas Muhammadiyah Yogyakarta, Jl. Lingkar Selatan, Tamantirto, Kasihan, Bantul 55183, Indonesia

2 The University of Sydney, Sydney, NSW 2006, Australia 